\title{
Introduction: microbes, networks, knowledge-disease ecology and emerging infectious diseases in time of COVID-19
}

\author{
Mark Honigsbaum ${ }^{2} \cdot$ Pierre-Olivier Méthot $^{1}$
}

Published online: 23 June 2020

(C) Springer Nature Switzerland AG 2020

\begin{abstract}
This is an introduction to the topical collection Microbes, Networks, Knowledge: Disease Ecology in the twentieth Century, based on a workshop held at Queen Mary, University London on July 6-7 2016. More than twenty years ago, historian of science and medicine Andrew Mendelsohn asked, "Where did the modern, ecological understanding of epidemic disease come from?" Moving beyond Mendelsohn's answer, this collection of new essays considers the global history of disease ecology in the past century and shows how epidemics and pandemics have made "microbes complex".
\end{abstract}

Keywords Population ecology $\cdot$ Parasitology $\cdot$ Bacteriology $\cdot$ Tropical medicine Networks · Emerging and re-emerging infections · 1918-1919 influenza pandemic · Epidemics $\cdot$ Virulence $\cdot$ Ecology of knowledge $\cdot$ SARS-CoV-2 pandemic

We dedicate this topical collection to the memory of Mirko D. Grmek (1924-2000), who was the founding editor of History and Philosophy of the Life Sciences and a pioneer in the field of history and the historiography of "emerging infections".

In 1998, the historian of science and medicine J. Andrew Mendelsohn posed a deceptively simple question. "Where," he asked, "did the modern, ecological understanding of epidemic disease come from?" Helpfully, Mendelsohn provided an answer. Arguing that it was difficult to see how "the fledgling ideas and methods

Pierre-Olivier Méthot

p.olivier.methot@gmail.com

Mark Honigsbaum

mark.honigsbaum@city.ac.uk

1 Université Laval, Quebec City, Canada

2 City, University London, London, UK 
of upstart population ecology, or the premises of parasitology could have conquered bacteriology," he suggested these perspectives were already present in medical microbiology at its inception but re-emerged more strongly in the interwar and post-war period, often from within the very institutions most closely associated with germ theory and the reductionist pursuit of vaccines and chemotherapeutic drugs (Mendelsohn 1998, pp. 303-304). In particular, Mendelsohn chided the Australian immunologist and Nobel Prize winner Frank Macfarlane Burnet for having "left out half the story" when in 1940 he had claimed in Biological Aspects of Infectious Disease that the new "ecological point of view" had been due to the ascendance of other scientists over "bacteriologists who had been trained as medical men" (Burnet 1940, pp. 2-3).

Coming in the wake of renewed scholarly interest in the 1918-1919 influenza pandemic (Honigsbaum 2013, 2019) —an outbreak that according to Mendelsohn had posed "complex" new challenges for public health-Mendelsohn's answer struck many as persuasive at the time, but in the two decades since it has become clear that his answer was incomplete. In his pioneering essay on the "natural histories of disease," the historian of medicine Warwick Anderson offered a partial riposte to Mendelsohn by showing how Burnet's ideas had been fashioned by his interactions with animal ecologists in the 1920s and 1930s, and the disease challenges that confronted microbiologists working in colonial and postcolonial settler societies (2004; see also Anderson 2016). Since then case-studies of particular scientific figures and institutions that echo Anderson's findings have been accumulating (Anderson 2017; Honigsbaum 2016, 2017a, b; Jones 2017; Mason Dentinger 2016; Way 2015; Méthot 2012). Nevertheless, it remains to be explained how scientists came to postulate an "evolutionary time scale" and to develop "integrative models" in place of a more static view of the relation between environment, health, and disease, to use Anderson's words (2004, p. 42).

Adding to the complexities about the multiple intellectual origins of this nonreductionist perspective, terms such as "virulence," "pathogen," and "infection" have been historically defined in different ways in biology and medicine, creating semantic confusion about the nature of biological processes in host-parasite interactions (Méthot and Dentinger 2016). Furthermore, local scientific traditions and research styles differ from one context to another, but scholarship on the history of disease ecology has mostly concentrated on dominion science and especially on American, Australian, and British contexts, even though similar concepts flourished elsewhere, for instance in Russia, as the study by Susan Jones and Anna Amramina in this collection demonstrates (Jones and Amramina 2018). Last but not least, in writing the first draft of the natural history of disease, prominent scientists like Macfarlane Burnet and Joshua Lederberg have selectively identified prestigious forerunners of their ecological ideas and suggested key influences on their work, while leaving out other potentially important sources and antecedents (Anderson 2004).

Thus, a global picture of this multi-site tradition, of its actors and their personal and professional relations, and of its particular place within twentieth-century biomedical science is still wanting. If disease ecology emerged in the 1930s and formed a specific "analytic framework for understanding the interactions of microorganisms and macrobial hosts" (Anderson 2016, p. 242), it still remains to be characterized 
with respect to other trends in the biomedical sciences in the past century, including the rise of experimentalism and the earlier development of medical geography, as well as the intellectual exchanges that helped shape the field of disease ecology. For instance, what role did transnational scientific networks play in the propagation and circulation of ecological ideas, and how and to what extent did microbiologists forge alliances with researchers in allied fields? Reconstructing these "ecologies of knowledge," to invoke Charles Rosenberg's useful phrase, and the borders between them, is no easy task. As Anderson points out, since historians of science and medicine took up Mendelsohn's question in earnest they have described multiple influences on the field's formation and composition. These include not only parasitology and animal ecology, but veterinary pathology, medical geography, and institutions concerned with the control of agricultural pests. In the process, medical researchers came to adopt a very different language to that employed by microbe hunters, one that eschewed the old bacteriological metaphors of a "war" or "struggle" with microbes in favour of a more dynamic, interactive, and cooperative vision of health (see Lederberg 2000). Whether or not it was couched in explicitly ecological language, it was a vision that tended to see disease as the result of temporary imbalances or disturbances of biological relationships, rather than as something that could or ought to be conquered or eradicated. And it was a vision that was explicitly sympathetic to Darwinian perspectives and that was prepared to embrace long evolutionary time frames. In so doing, it could not help but provoke deep philosophical questions about what the French bacteriologist Charles Nicolle (1930) termed the "birth, life and death of infectious diseases" and the waxing and waning of epidemics in different historical epochs (see Méthot 2019a, this issue), and what the Rockefeller researcher René Dubos called the "symbiosis between humankind and earth" (see Honigsbaum 2017a, b).

In the summer of 2016 we invited a diverse group of scholars to re-interrogate Mendelsohn's question at a workshop at Queen Mary, University London. ${ }^{1}$ Most of us were historians of science, medicine and technology, but with a view to opening up interdisciplinary perspectives the group also included anthropologists, biologists, and epidemiologists specializing in emerging infectious diseases (EIDs). As the latter reminded us, in recent years a succession of epidemics of SARS, Ebola, and Zika, has driven home the importance of ecological perspectives in pandemic planning. Yet, while it is now widely recognised that the disturbance of natural habitats can result in zoonotic pathogens being dislodged from their ecological niches and infecting human populations, we still lack a comprehensive account of when and how disease ecology entered the medical mainstream. If anything, the need for such an account has become even more urgent following the emergence in December 2019 of the novel coronavirus (SARS-CoV-2) and the pandemic of COVID-19

\footnotetext{
${ }^{1}$ Here is the list of speakers at the conference: Anna A. Amramina, Warwick Anderson, Jon Arrizabalaga, Christoph Gradmann, David Heymann, Mark Honigsbaum, Susan D. Jones, Christos Lynteris, Andrew Mendelsohn, Pierre-Olivier Méthot, David Morens, Anne-Marie Moulin, Michael Kosoy, Nilsh Chr. Stenseth, and Frédéric Vagneron. Full programme can be found here: https://projects.history.qmul. ac.uk/making-microbes/.
} 
that followed. Although at time of writing the source of SARS-CoV-2 has not been established, the fact that it shares $96 \%$ of its genes with a coronavirus previously isolated from wild bats, and that the earliest human cases occurred in or a near a wild animal market in Wuhan, in central China, points strongly to the pandemic's zoonotic origins and that the world should be prepared for further pandemics triggered by "spillover" events. As three of the leading experts on zoonoses and pandemics put it in a paper in the New England Journal of Medicine, "We have created a global, human-dominated ecosystem that serves as a playground for the emergence and host-switching of animal viruses" (Morens et al. 2020, p. 1293). Back in 2007, in the aftermath of the SARS epidemic, a research team from the University of Hong Kong warned the scientific community that "the presence of a large reservoir of SARS-CoV-like viruses in horseshoe bats, together with the culture of eating exotic animal in Southern China, is a time bomb" (Cheng et al. 2007, p. 683). Sadly, that call was not taken sufficiently seriously. We can only hope that the present pandemic of COVID-19 has finally put to rest Macfarlane Burnet's and David O. White's complacent and dangerous assumption that "the most likely forecast about the future of infectious disease is that it will be very dull” (Burnet and White 1972, p. 263).

In our view the failure to provide a comprehensive account of the field lies partly with medical historians who have applied the term "disease ecology" avant la lettre, reading it back onto historical texts from the 1930s and 1940s, and perhaps even before. In fact, as Jon Arrizabalaga shows, the term first appeared in a 1961 article entitled Studies in Disease Ecology by the French medical geographer Jacques May. However, 3 years earlier, May had already published on The Ecology of Human Disease and in 1952 he had proposed replacing the phrase "medical geography" with "ecology of health and disease," so clearly the ideas were present in his thought at an earlier date. May's ideas were to influence the Croatian physician and historian of science and medicine Mirko D. Grmek in the 1960s (e.g. "pathocenosis"), who developed his ideas of disease ecology further when writing the first history of AIDS and introducing a taxonomy of the concept of "emerging disease" in the early 1990s (Arrizabalaga 2018, this issue; see also Méthot 2019b).

Inspired by the teaching of Nicolle, the French biologist and physician Hervé Harant also promoted the science of "medical ecology" in the Montpellier area in the mid-twentieth century. However, instead of drawing a sharp boundary between medical geography and disease ecology he insisted on their being continuous with one another. Drawing on the writings of geographer Maximilien Sorre and the concept of a "pathogen complex", Harant relied on the then emerging ecological terminology, but this understanding of ecology had more to do with the natural history tradition than with population studies as such. Furthermore, neither May nor Harant referred to what Burnet called the "ecological point of view" or cited the writings of their fellow Frenchman, the Rockefeller microbiologist René Dubos. This despite the fact that by the 1960s Dubos was fast developing a reputation as an apostle of the burgeoning environmental movement and was increasingly employing horticultural metaphors to express his unease with short-term medical fixes, such as antibiotics, and to distance himself from eradicationist perspectives. Indeed, though towards the end of his career Dubos acknowledged that he had had few occasions to use the word ecology before the 1960s, he claimed that ever since 1924, when he had embarked 
on a career as an experimental biologist, he had "looked at things from an ecological point of view" (Honigsbaum 2017a, b, p. 15) The result was that rather than take Pasteur's "pure culture" road, Dubos decided it would be more profitable to take the road that "lead to physiological and ecological studies" (Honigsbaum 2017b, p. 3).

Dubos's assertion points to a fundamental definitional and methodological problem: namely, what exactly does it mean to have an "ecological point of view" and is such a viewpoint contiguous with both "disease ecology" and "medical ecology?" Furthermore, if, as May and Harant appear to have believed, disease ecology is closely related to medical geography, what distinguishes one from the other and does it matter if the person invoking ecological perspectives considers themselves primarily a medical researcher or a geographer of disease? And more importantly: what did "disease ecology" mean to scientists such as Dubos, Meyer, and Burnet? As historians, we are confronted with the issue of anachronism when using the phrase "disease ecology" retrospectively since ecology was not a full-fledged scientific discipline until the 1950s (Tilley 2011). The phrase has multiple meanings, and not only refers to a particular scientific field but to various political movements with different agendas. As the papers collected in this thematic issue make clear, scientists—when they did provide a definition_-adapted the term ecology to fit their own particular projects. Indeed, although each of these ecologically-oriented medical researchers tended to represent themselves as singular, and, as Anderson has observed, "as the sole author of the idea, and rarely cited others, even those linked to him by education or friendship" (2004, p. 41), none of them worked in a vacuum but were connected by networks of scientific exchange and shared intellectual passions.

A good example comes from the two papers with which we open the collection. At first glance, René Dubos's investigations of the tubercle bacillus at the Rockefeller Institute in New York in the 1940s would seem to have little do with Frank Fenner's classic study of myxomatosis in Australia in the 1950s, but, as Honigsbaum and Anderson show, both researchers were fascinated with the phenomenon of virulence and the environmental and ecological conditions governing host resistance to infection and disease. Moreover, in 1948, Fenner, at Burnet's suggestion, had spent 11 months at Dubos's laboratory at the Rockefeller Institute. There, he had assisted Dubos in his investigations of the chemical and morphological properties of the tubercle bacillus and the role of metabolic processes in converting latent tubercular infections into full-blown cases of the disease. The result was that by the time Fenner returned to Australia in 1950 and renewed his association with Burnet he was primed to apply these holistic perspectives derived from the laboratory study of mycobacteria—what might be termed physiological ecology — to host-parasite interactions in the field. His opportunity came in 1951 when he was invited to lead an "ecological study of mosquitoes" with a view to explicating their role in the transmission of the myxoma virus, which had been introduced to Australia a few years earlier in an effort to curb rabbit populations. Fenner's study, which drew on what Anderson calls "local ecologies of knowledge," in particular scientific networks operating through Australia's Council of Scientific and Industrial Research, was the first to trace the coevolution of host resistance and parasite virulence in a natural setting in real-time. In the process, Fenner showed how natural selection served to regulate the virulence of the myxoma virus and stabilize host-parasite 
interactions in the wild. Little wonder that Dubos, who followed the progress of Fenner's study closely, hailed it as an example of "host-parasite ecology" and that Fenner later described Dubos and Burnet as his two most important intellectual influences (Honigsbaum 2017a, b, this issue, p. 14). Perhaps more significantly from the point of view of the trajectory of ecological ideas in the post-war period, Anderson shows how Fenner's study "offered techniques that could be applied equally well to biological warfare among humans," thereby underlining the "congruence of the ecological mindset with prevailing cold-war thought styles" (Anderson 2017, p. 13).

Another example of the operation of transnational scientific networks in fostering ecological ideas was the pioneering plague research conducted by the Russian zoologist Evgeny Pavlovsky and his Soviet colleagues in the 1920s. Best known for his concept of "natural nidality" - a term derived from the Russian word "ochag", meaning "hearth" or "home"-Pavolvsky appears to have had a much wider influence that was previously supposed, and not just on thinkers sequestered behind the Iron Curtain. On the contrary, Susan Jones and Anna Amramina maintain that there was "a surprisingly vigorous knowledge exchange with Western ecologists and biomedical scientists even under the most difficult conditions" (Jones and Amramina 2018, this issue). For instance, Pavlovksy was in regular contact with Charles Nicolle in Tunis, and even visited the Pasteur Institute in Tunisia on the eve of the First World War (see Méthot 2019a, this issue). The two men exchanged a number of letters over the years, together with books and laboratory materials, and shared their ideas about the nature of infectious processes. While medical geography relied on the two-dimensional mapping of disease ranges onto places, the Soviet "natural focus" framework located disease explicitly in what Jones and Amrarmina describe as "spaces of interaction between components of non-human assemblages in nature." It was an order of analysis in which humans were de-centred and secondary. Instead, Pavlovksy and his colleagues focused on the mutual influences between the key constituents of plague systems-rodents, microorganisms, fleas-and factors such as landscape, climate, and human cultures. In so doing, Soviet ecologists were able to actively incorporate ideological concepts into their plague studies, particularly in the Soviet borderlands where ecology provided a philosophical and material framework for furthering ideological goals of "sanitizing" colonial landscapes. In this way, Jones and Amramina argue, the natural focus framework was "entangled in political as well as material ecologies of knowledge and practice." Indeed, to the extent that the framework "provided scientific validation and guidance for Stalinistera colonization and development projects," this was a key basis of its success.

These ecological perspectives had particular appeal to microbiologists working in tropical or settler environments - hence Burnet's "ecological point of view"-but for many years lacked a unifying term. Instead they found expression in the language of "host-parasite interactions," "equilibrium states", "immune balance", "latent infections" and changes in virulence and pathogenicity. To complicate the picture, throughout the period when these ideas were making inroads into microbiology, the laboratory continued to be the place where scientific breakthroughs and the reputations of medical researchers were made. It was the era of "microbe hunting" and the search for specific chemotherapeutic agents-one in which medical scientists cultivated an image as slayers of germs and held out the promise that medicine 
would triumph over the microbes of infectious disease and bring an eventual end to epidemics. Yet as Christoph Gradmann argues, this approach entailed a rather static view of microbes, or one in which evolution of resistance to antibiotics occurred over long Darwinian time periods, although by the 1960s ecological perspectives were also making inroads into infection medicine as hospitals became "hothouses" for drug-resistant microbes (Gradmann 2018, this issue).

A key implication of our study is that there was nothing inevitable about the adoption of ecological perspectives by medical researchers in the interwar period and the integration of these ideas into laboratory research and public health in the decades after the Second World War. Rather, such ideas often ran counter to the dominant bacteriological paradigm and institutional and commercial research agendas, including Cold War biological warfare research, aimed at the manufacture of vaccines and chemotherapies. Indeed, as Dubos' early warnings about the dangers of antibacterial resistance illustrate, it took many years for these insights to find their way into medical schools and to be taken up by medical authorities. Furthermore, while for some medical thinkers a focus on the ecological, environmental and social factors governing host-pathogen interactions and the evolution or resistance fostered scepticism about short-term technological 'fixes' for medical problems, for others these ecological insights were seen as an adjunct to disease control and systems designed to enhance pandemic prevention. In this respect, the study has important implications for current policy debates around polio eradication and the monitoring of pathogens, such as influenza, that have long been considered pandemic threats, as well as other putative pandemic threats listed by the World Health Organization in its 2018 Research and Development blueprint. ${ }^{2}$

Our study also provides much needed historical context for current policy debates around "emerging infectious diseases". This concept is closely associated with a 1992 report by the Institute of Medicine and the molecular biologist Joshua Lederberg. A former student of Dubos, Lederberg drew on ecological insights associated with Dubos's and Burnet's writings in proposing his own view of a natural history of disease (see Méthot and Fantini 2014). However, while Dubos' and Burnet's ideas exerted a huge influence over Lederberg and other medical researchers who came of age in the 1950s and 1960s, we do not know precisely how these ideas found their way into epidemiology and public health teaching. Nor can we say precisely what became of these ideas in the 1970s and 1980s-periods marked by the Legionnaires' Disease and swine flu outbreaks, and the advent of HIV/AIDs-much less why the EID concept took precisely the form it did in the early 1990s (but see Weir and Mykhalovskiy 2010). To answer this question, and provide a more comprehensive understanding of why it is that modern practices of disease control and

\footnotetext{
2 As of 2018, the WHO listed eight priority pathogens: Crimean-Congo Haemorrhagic Fever; Ebola and Marburg; MERS Co-V and SARS; Lassa Fever; Nipah; Rift Valley Fever; Zika, and a putative yet-to-bediscovered pathogen labeled "Disease X". WHO, "2018 Annual review of diseases prioritized under the Research and Development Blueprint”, February 6-7, 2018, accessed March 26, 2002, http://www.who. int/blueprint/priority-diseases/en/.
} 
preventive medicine are crafted in the way they are, more work needs to be done to fill in developments in the period from 1970 to 1990.

To conclude, Mendelsohn's claim that modern ideas of disease ecology were already present in bacteriological epidemiology at the inception of medical microbiology is only true if one adopts a narrow and self-limiting definition of disease ecology. Instead, we argue that the modern notion of disease ecology rests on the notion that microbial pathogens reside in ecological niches in equilibrium states and that it is the disturbance of these harmonious natural environments that trigger epidemics and pandemics. It is only by broadening our understanding of the historical origins of Mendelsohn's "modern, ecological understanding of epidemic disease" and the medical researchers and scientific networks responsible for the integration of such perspectives into medical microbiology and public health, that historians will arrive at a more definitive account of the intellectual origins of these ideas. This is not merely an intellectual exercise. As the debate over the role of ecological causation in SARS-CoV-2 demonstrates, the history of modern ideas of disease ecology can not only help us make sense of the past, it can also illuminate current scientific debates around emerging infectious diseases, and the interaction between biological, economic, and cultural factors in current pandemic emergencies, as well as others that may be lurking beyond the horizon.

\section{References}

Anderson, W. (2004). Natural histories of infectious disease: Ecological vision in twentieth-century biomedical science. Osiris, 2(19), 39-61.

Anderson, W. (2016). Postcolonial ecologies of parasite and host: Making parasitism cosmopolitan. Journal of the History of Biology, 49, 241-259.

Anderson, W. (2017). Nowhere to run, rabbit: The cold-war calculus of disease ecology. History and Philosophy of the Life Sciences. https://doi.org/10.1007/s40656-017-0140-7.

Arrizabalaga, J. (2018). At the intersection of medical geography and disease ecology: Mirko Grmek, Jacques May and the concept of pathocenosis. History and Philosophy of the Life Sciences. https:// doi.org/10.1007/s40656-018-0236-8.

Burnet, F. M. (1940). Biological aspects of infectious disease. Cambridge: Cambridge University Press.

Burnet, F. M., \& White, D. O. (1972). Natural history of infectious disease (4th ed.). Cambridge: Cambridge University Press.

Cheng, V. C. C., Lau, S. K. P., Woo, P. C. Y., \& Yuen, K. W. (2007). Severe acute respiratory syndrome coronavirus as an agent of emerging and reemerging infection. Clinical Microbiology Reviews, 20(4), 660-694.

Gradmann, C. (2018). From lighthouse to hothouse: Hospital hygiene, antibiotics and the evolution of infectious disease, 1950-1990. History and Philosophy of the Life Sciences. https://doi.org/10.1007/ s40656-017-0176-8.

Honigsbaum, M. (2013). A history of the great influenza pandemics: Death, panic and hysteria, 18301920. London: I. B. Tauris Academic.

Honigsbaum, M. (2016). 'Tipping the balance': Karl Friedrich Meyer, latent infections, and the birth of ideas on disease ecology. Journal of the History of Biology, 49(2), 261-309.

Honigsbaum, M. (2017a). René Dubos, tuberculosis, and the "ecological facets of virulence". History and Philosophy of the Life Sciences. https://doi.org/10.1007/s40656-017-0142-5.

Honigsbaum, M. (2017b). The road taken: René Dubos's journey from microbiologist to ecologist. Rockefeller Archive Center Research Reports. https://www.issuelab.org/resource/road-taken-rene-dubos -journey-from-microbiologist-to-ecologist.html. Accessed 14 May 2020. 
Honigsbaum, M. (2019). The pandemic century: One hundred years of panic, hysteria and hubris. London: Hurst.

Jones, S. (2017). Population cycles, disease, and networks of ecological knowledge. Journal of the History of Biology, 50(2), 357-391.

Jones, S., \& Amramina, A. (2018). Entangled histories of plague ecology in Russia under the USSR. History and Philosophy of the Life Sciences. https://doi.org/10.1007/s40656-018-0220-3.

Lederberg, J. (2000). Infectious history. Science, 288(5464), 287-293.

Mason Dentinger, R. (2016). Patterns of infection and patterns of evolution: How a malaria parasite brought 'monkeys and man' closer together in the 1960s. Journal of the History of Biology, 49(2), 359-395.

Mendelsohn, J. A. (1998). From eradication to equilibrium: How epidemics became complex after World War I. In C. Lawrence \& G. Weisz (Eds.), Greater than the parts: Holism in biomedicine, 1920 1950 (pp. 303-331). Oxford: Oxford University Press.

Méthot, P.-O. (2012). Why do parasites harm their host? On the origin and legacy of Theobald Smith's 'law of declining virulence' 1900-1980. History and Philosophy of the Life Sciences, 34(4), 561-601.

Méthot, P.-O. (2019a). 'Birth, life, and death of infectious diseases': Charles Nicolle (1866-1936) and the invention of medical ecology in France. History and Philosophy of the Life Sciences. https://doi. org/10.1007/s40656-018-0238-6.

Méthot, P.-O. (2019b). Mirko Grmek's investigative pathway. In M. D. Grmek, Pathological Realities: Essays on disease, experiments, and history, Edited, Translated and with an Introduction by PierreOlivier Méthot, foreword by Hans-Jörg Rheinberger (pp. 1-28). New York: Fordham University Press.

Méthot, P.-O., \& Fantini, B. (2014). Medicine and ecology: Historical and critical perspectives on the concept of 'emerging disease'. Archives Internationales d'histoire des Sciences, 64, 213-230.

Méthot, P.-O., \& Mason Dentinger, R. (2016). Ecology and infection: Studying parasite interactions at the interface of biology and medicine. Journal of the History of Biology, 49(2), 231-240.

Morens, D. M., Daszak, P., \& Taubenberger, J. K. (2020). Escaping Pandora's box-Another novel coronavirus. The New England Journal of Medicine, 382, 1293-1295.

Nicolle, C. (1930). Naissance, vie et mort des maladies infectieuses. Paris: Félix Alcan.

Tilley, H. (2011). Africa as living laboratory: Empire, development, and the problem of scientific knowledge, 1870-1950. Chicago: University of Chicago Press.

Way, A. (2015). The invisible and indeterminable value of ecology: From malaria control to ecological research in the American south. Isis, 106(2), 310-336.

Weir, L., \& Mykhalovskiy, E. (2010). Global public health vigilance: Creating a world on alert. Abingdon: Routledge.

Publisher's Note Springer Nature remains neutral with regard to jurisdictional claims in published maps and institutional affiliations. 